\title{
Potenciais evocados auditivos pré e pós-tratamento em indivíduos gagos: estudo piloto ${ }^{* * * * * *}$
}

\author{
P300 event-related potentials in stutterers pre and post treatment: a \\ pilot study
}

\author{
Claudia Regina Furquim de Andrade* \\ Fernanda Chiarion Sassi** \\ Carla Gentile Matas*** \\ Ivone Ferreira Neves**** \\ Vanessa Oliveira Martins*****
}

* Fonoaudióloga. Professora Titular do
Departamento de Fisioterapia,
Fonoaudiologia e Terapia Ocupacional
da Faculdade de Medicina da
Universidade de São Paulo (FMUSP).
Endereço para correspondência: Rua
Cipotanea, 51 - Campus Cidade
Universitária - São Paulo - SP - CEP
05360-160 (clauan@ usp.br).
** Fonoaudióloga. Doutora em
Ciências pela FMUSP. Departamento de
Fisioterapia, Fonoaudiologia e Terapia
Ocupacional da FMUSP.

**** Fonoaudióloga. Doutora em Distúrbios da Comunicação Humana pela Universidade Federal de São Paulo. Professor Adjunto do Departamento de Fisioterapia, Fonoaudiologia e Terapia Ocupacional da FMUSP.

**** Fonoaudióloga. Doutora em Ciências pela FMUSP. Departamento de Fisioterapia, Fonoaudiologia e Terapia Ocupacional da FMUSP

***** Fonoaudióloga. Doutora em Semiótica e Linguística Geral pela Faculdade de Filosofia, Letras e Ciências Humanas da Universidade de São Paulo. Fonoaudióloga do Centro de Saúde Samuel Barnsley Pessoa.

****** Trabalho Realizado no Departamento de Fisioterapia, Fonoaudiologia e Terapia Ocupacional da Faculdade de Medicina da Universidade de São Paulo.

Cartas sobre Pesquisa

Artigo Submetido a Avaliação por Pares

Conflito de Interesse: não

Recebido em 04.07.2007.

Revisado em 28.08.2007

Aceito para Publicação em 29.10.2007.

\section{Abstract}

Background: P300 event-related potential has been used as an instrument to establish the diagnosis of several disorders as well as to assess therapeutic outcomes. Aim: to investigate the relationship between stuttering amelioration and cerebral activity. Method: P300 event-related potentials were obtained in three adult males, all stutterers, aged 20 to 31 years, pre and post-treatment, verifying changes in wave amplitude and latency between waves. Results: results indicate a significant positive correlation between the reduction in the percentage of stuttered syllables and the improvement in wave amplitude for the right ear. Conclusion: stutterers can exhibit different patterns of interhemispheric activity with a tonal P300 task after undergoing a fluency-enhancing program.

Key Words: Stuttering; Auditory Evoked Potentials; Methods.

\section{Resumo}

Tema: os potenciais auditivos evocados têm sido utilizados como instrumento para determinar o diagnóstico de diversas desordens, assim como para avaliar os resultados de processos terapêuticos. Objetivo: investigar a relação entre a melhora da gagueira e a atividade cerebral. Método: foram investigados os potenciais auditivos evocados pré e pós-tratamento de três indivíduos do sexo masculino, todos com gagueira e idades entre 20 e 31 anos, verificando mudanças na amplitude do sinal e na latência entre ondas. Resultados: os resultados indicam uma correlação positiva entre a redução da porcentagem de sílabas gaguejadas e a melhora na amplitude de onda para a orelha direita. Conclusão: indivíduos gagos podem exibir diferentes padrões de atividade inter-hemisférica em tarefa com o P300 após serem submetidos a um programa de promoção da fluência.

Palavras-Chave: Gagueira; Potencias Auditivos Evocados; Métodos. 


\section{Introduction}

One of the more recent applications of P300 has been the monitoring of experience-related changes of neural activity. Due to plasticity, the Central Nervous System is capable of reorganization as a consequence of stimulation. Several studies refer changes, especially in the P300 event-related potential (wave latency and amplitude) after a period of stimulation (1-2). As a consequence of improvement in the auditory perception, the same authors verified an increase in wave amplitude and decrease in wave latency. Eggermont (3) suggests that wave amplitude is highly influenced by individual characteristics and wave latency by the time a neural activity takes to run through the auditory pathway. This includes synaptic delay and neural conduction delay. Therefore, P300, might provide valuable information related to hemispheric processing in stutterers. However, results in individuals who stutterer have been contradictory.

A few authors found no differences between individuals who stutter and do not stutter in the latency of P300 response (4) while others found that P300 were higher in amplitude over the left hemisphere than the right hemisphere for most of the tested stutterers, while the participants in the fluent group exhibited P300 that were higher in the right hemisphere (5). Other studies, using brainevoked response testing, revealed no relationship between brainstem-evoked response and severity of stuttering(6) and presented heterogeneous, regarding cortical hemispheric differences, for stutterers(7).

The purpose of the present study was to investigate the relationship between stuttering amelioration and cerebral activity. P300 event-related potentials were obtained pre and post-treatment in order to investigate changes in signal amplitude and in the latency between waves.

\section{Method}

\section{Participants}

This study received prior approval of the Ethics Committee of the Institution (CAPPesq HCFMUSP 1021/03) and informed consent was obtained from all of the participants.

Three right-handed native Portuguese-speaking males who stutter, ranging in age from 20 to 31 years $(M=26.6)$, volunteered to participate in the present study. All participants had normal puretone audiometric thresholds (8), normal middle ear function (9) and reported negative history of neurological, motor control or psychiatric conditions.

All participants reported gradual development of disfluencies during early childhood, family history for stuttering and none of them had previously undergone any kind of therapy, having scored in the very severe (1) and moderate range (1) on the Stuttering Severity Instrument (SSI-3) (10). Interjudge reliability (Kappa coefficient) calculated for all subjects' speaking samples was .92 and .91 , respectively.

Speech samples and disfluency analyses

A speech sample was obtained from each participant pre and post treatment. These samples were evaluated according to the Fluency Profile Protocol (11). In addition, the SSI-3 was used to estimate the level of stuttering severity.

Late auditory evoked potential (LAEP) test protocol

For evoked potential testing (pre and post treatment), a Biologic Traveler Express System was used for acquisition of data and for generation of the different probe stimuli. Copper cup recording electrodes were placed on the participants' mastoids (A1 and A2) and vertex (Cz), with Fpz (forehead) as reference, according to the international 10-20 system. All electrode impedances were maintained at levels of 5000 ohms or below. TDH-39 earphones were used to deliver the tonal stimuli. Tests were conducted in a quiet room with the participant sitting in a reclining chair. To minimize possible artifacts due to stuttering during the recording session, participants were required to respond using hand signals.

An "oddball" stimulus presentation pattern was employed for evoking the P300 component of the late auditory evoked response. The oddball pattern consists of the presentation of a stream of two different frequency tones, the two tones being referred to as either rare or frequent tone. The probability of either tone being presented at each stimulus interval was predetermined with a $20 \%$ probability of the rare tone being presented and, consequently, an $80 \%$ probability of presentation of the frequent tone. A $1000 \mathrm{~Hz}$ tone was used for the frequent tone whereas a $1500 \mathrm{~Hz}$ tone served as the rare tone. Participants were instructed to raise a finger in response to each presentation of rare tone stimuli. The number of participant responses to rare tone stimuli was examined after each run. No 
participant's count of the rare tones was inaccurate by more than three in the present study, thus indicating a high level of attention to the counting task.

Due to the small number of participants and with the purpose of verifying variability in the results of $\mathrm{P} 300$, measurements of $\mathrm{P} 300$ obtained from healthy adults, speakers of the Brazilian Portuguese language, and already described in the literature where used as a control group (mean latency values: right ear-309.88ms; left ear - 308.84ms) (12).

\section{Stuttering therapy}

After audiological and speech testing, all of the participants underwent a fluency promotion program monitored by surface electromyography (SEMG), so that the muscle strength used during speech production could be objectively controlled (biofeedback) (13).

A four channel SEMG equipment (EMG System Brazil), with RMS (Root Mean Square) signal conversion was used. Disc $\mathrm{Ag} / \mathrm{Cl}$ bipolar electrodes (Medtrace Mini), with $10 \mathrm{~mm}$ of diameter, were placed on the middle portion of the inferior lips (orbicularis oris) and digastric, on the right masseter and on the right side of the neck (laterally above the thyroid prominence).

\section{Results}

For the analyses of the results the Paired TTest and Pearson Correlation were used with a significance level of $10 \%$ (14).

Observing the overall results (Table 1), the statistical analyzes, comparing pre and post treatment data, indicates significant difference only for atypical disfluencies and percentage of stuttered syllables (reduction).

Although the parameters of wave latency and amplitude are within the normal limits for all subjects, changes were observed in the post treatment analyses suggesting a better discrimination oddball stimulus patterns. Analyzing the results as a group, the statistical analyzes comparing pre and post treatment results indicate no significant difference for any of the tested aspects (Table 2).

In an attempt to verify if a relation exists between the speech measures and P300, the Pearson Correlation was calculated for all of the analyzed aspects. For this test, the percentage of improvement for each individual in each assessed aspect was considered. The test indicates a positive correlation is observed between the decrease in the percentage of stuttered syllables and the improvement in wave amplitude for the right ear $(\mathrm{r}=0.994$; $\mathrm{p}$-value $=0.073$.

TABLE 1. Summary table of the speech measures analyses.

\begin{tabular}{|c|c|c|c|c|c|c|c|c|c|c|c|c|}
\hline \multirow[t]{2}{*}{ Subject } & \multicolumn{2}{|c|}{ typical disfl. } & \multicolumn{2}{|c|}{ atypical disfl. } & \multicolumn{2}{|c|}{ wmp } & \multicolumn{2}{|c|}{ spm } & \multicolumn{2}{|c|}{$\%$ ss } & \multicolumn{2}{|c|}{$\begin{array}{c}\text { severity } \\
\text { SSI }\end{array}$} \\
\hline & pre & post & pre & post & pre & post & pre & post & pre & post & pre & post \\
\hline 1 & 22 & 23 & 73 & 39 & 16.3 & 31.8 & 29.6 & 59.4 & 36.5 & 19.5 & V. sev & Sev. \\
\hline 2 & 33 & 27 & 23 & 14 & 46.6 & 46.7 & 94.5 & 83.3 & 11.5 & 7.0 & Mod. & Mod \\
\hline 3 & 25 & 16 & 24 & 3 & 74.5 & 101.1 & 144.6 & 210.5 & 12.0 & 1.5 & Mod. & Nor. \\
\hline $\begin{array}{c}\text { P-Value } \\
(\mathrm{p}<0.1)\end{array}$ & \multicolumn{2}{|c|}{0.256} & \multicolumn{2}{|c|}{$0.098 *$} & \multicolumn{2}{|c|}{0.209} & \multicolumn{2}{|c|}{0.333} & \multicolumn{2}{|c|}{ 0.098* } & \multicolumn{2}{|c|}{ - } \\
\hline
\end{tabular}

TABLE 2. Summary table P300: wave latency and amplitude.

\begin{tabular}{|c|c|c|c|c|c|c|c|c|}
\hline \multirow[t]{3}{*}{ Subject } & \multicolumn{4}{|c|}{ latency } & \multicolumn{4}{|c|}{ amplitude $(\mu v)$} \\
\hline & \multicolumn{2}{|c|}{ right ear } & \multicolumn{2}{|c|}{ left ear } & \multicolumn{2}{|c|}{ right ear } & \multicolumn{2}{|c|}{ left ear } \\
\hline & pré & post & pre & post & pré & post & pré & post \\
\hline 1 & 330 & 290 & 326 & 250 & 10.38 & 10.62 & 14.37 & 6.44 \\
\hline 2 & 396 & 400 & 350 & 350 & 9.7 & 9.7 & 5.2 & 11.5 \\
\hline 3 & 370 & 342 & 338 & 334 & 8.23 & 11.7 & 4.44 & 11.37 \\
\hline $\begin{array}{c}\text { P-Value } \\
(\mathrm{p}<0.1)\end{array}$ & \multicolumn{2}{|c|}{0.246} & \multicolumn{2}{|c|}{0.393} & \multicolumn{2}{|c|}{0.384} & \multicolumn{2}{|c|}{0.751} \\
\hline
\end{tabular}




\section{Discussion}

Although the results need further investigation and must be seen with caution, it seems that for those individuals for whom the fluency-enhancing program was most effective (a higher reduction in the percentage of stuttered syllables), there seems to be a higher activation of the left hemisphere (measured by the improvement in wave amplitude in the right ear) after treatment. Other findings indicated a reduction in wave latency for both left and right when comparing pre and post treatment testing.

It is also interesting to observe that improvement is more obvious when analyzing the behavioral measures (speech measures) when compared to the physiological measures (P300).

A few studies of functional neuroimaging have investigated neural activation under fluencyenhancing techniques such as choral speech, pacing or automatic speech (15-18). Although these techniques often demonstrated to improve speech dramatically, characterized by the normalization or decrease in activity of many cortical and subcortical areas, the fluency-enhancing effect is linked to the immediate presence of the external stimulus and have little, if any, carry-over in time or space once the stimulus is removed. The functional imaging studies here discussed have not documented any long-term effects of the fluencyenhancing condition.

Other authors investigated the immediate and long-term effects of an intensive behavioral suttering treatment using neuroimage (PET) (19). These authors observed changes in activation lateralization, as well as a general reduction in overaction, especially in the motor cortex, following treatment. Long-term follow-up testing, however, did not indicate normalization of activation, although it was observed that cortical and subcortical overactivation was significantly reduced. Important changes in neural activity were observed after treatment: increased activation in cerebellar and cortical sensorimotor regions in frontal and temporal cortex, especially in the left hemisphere.

\section{Conclusion}

Although P300, as already mentioned, does not give the exact site or sites of cerebral activation, the results of this study have demonstrated to some extent that differences in interhemispheric activation patterns can be measured pre and post treatment. Questions remain as to whether this type of testing can really differentiate individuals for whom therapy was successful from those for whom therapy was not effective. It would also be interesting to investigate if for those individuals who present improvement in both latency and wave amplitude, results of speech measures are more stable in a long term follow-up (indication of better maintenance).

Literature has very few studies about P300 and stuttering and those that exist do not compare results after therapeutic intervention. For this reason, the present study should be seen as exploratory.

Acknowledgements: Part of this research received financial support from FAPESP(Process no. 03/13526-9).

\section{References}

1. Kraus N, McGee T, Carrell T. Central auditory system plasticity associated with speech discrimination training. Journal Cognitive Neuroscience. 1995;7:25-32.

2. Tremblay K, Kraus N, McGee T. Central auditory plasticity: Changes in the N1-P2 complex after speechsound training. Ear and Hearing. 2001;22:79-90.

3. Eggermont JJ. Electric and magnetic fields of synchronous neural activity. In: Burkard RF, Don M, Eggermont JJ (Eds.). Auditory evoked potentials. Baltimore: Lippincott William \& Wilkins; 2006. p. 2-21.

4. Ferrand CT, Gilbert HR, Blood GW. Selected aspects of central processing and vocal motor function in stutterers and nonstutterers: P300, laryngeal shift, and vibratory onset. Journal of Fluency Disorders. 1991;16(2):101-15.
5. Morgan MD, Cranford JL, Burk K. P300 Event-Related Potentials in Stutterers and Nonstutterers. Journal of Speech, Language and Hearing Research. 1997;40:1334-40.

6. Blood IM, Blood GW. Relationship between stuttering severity and brainstem-evoked response testing. Perceptual Motor and Skills. 1984;59(3):935-8.

7. Rosanowski F, Hoppe U, Hies T, Moser M, Proschel U, Eysholdt U. Auditory speech-evoked cerebral cortex potentials in patients with stuttering syndromes. Laryngorhinootologie. 1998;77(12):709-14.

8. American National Standards Institute. Specification for audiometers (ANSI S3.6-1989). New York: ANSI; 1989.

9. American Speech-Language-Hearing Association. Guidelines for screening for hearing impairments and middle ear disorders. Asha. 1990;32(Supplement 2):17-24. 
10. Riley GD. Stuttering severity instrument for children and adults. Austin: Pro-Ed; 1994.

11. Andrade CRF de. Protocolo para avaliação da fluência da fala. Pró-Fono. 2000;12(2):131-4.

12. Matas CG, De Juan KR, Nakano RA. Middle and late latency auditory evoked potentials in adults with Aids. PróFono. 2006;18(2):171-6.

13. Sassi FC, Andrade CRF de. Acoustic analyses of speech naturalness: a comparison between two therapeutic approaches. Pró-Fono. 2004;16(1):31-8.

14. Maxwell DL, Satake E. Research and statistical methods in communication sciences and disorders. Canada: Thompson Delmar Learning; 2006.

15. Wu JC, Maguire G, Riley G, Fallon J, Lacasse L, Chin S et al. A positron emission tomography [18F] deoxyglucose study of developmental stuttering. Cognitive Neuroscience and Neuropsychology. NeuroReport. 1995;6:501-5.
16. Ingham RJ, Fox P, Ingham J, Zamarripa F, Martin C, Jerabek $\mathrm{P}$ et al. Functional lesion investigation of developmental stuttering with positron emission tomography. Journal of Speech and Hearing Research. 1996;39:1208-27.

17. Braun AR, Varga M, Starger S, Schulz G, Selbie JM, Carson RE et al. Altered patterns of cerebral activity during speech and language production in developmental stuttering: H2150 positron emission tomography study. Brain. 1997;120:761-84.

18. Fox PT, Ingham RJ, Ingham JC, Zamarripa F, Xiong JH, Lancaster JL. (2000). Brain correlates of stuttering and syllable production. A PET performance-correlation analysis. Brain. 2000;123:1985-2004.

19. De Nil LF, Kroll RM, Lafaille SJ, Houle S. (2003). A positron emission tomography study of short- and longterm treatment effects on functional brain activation in adults who stutter. Journal of Fluency Disorders. 2003;28:357-80. 